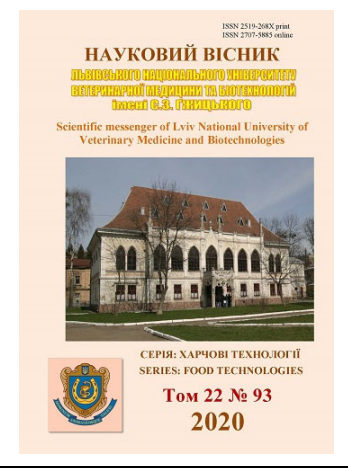

Науковий вісник Дьвівського національного університету ветеринарної медицини та біотехнологій імені С.3. Гжицького. Серія: Харчові технології

\author{
Scientific Messenger of Lviv National University \\ of Veterinary Medicine and Biotechnologies. \\ Series: Food Technologies
}

doi: $10.32718 /$ nvlvet-f9309

https://nvlvet.com.ua/index.php/food

UDC 637.3

\title{
Changes in protein substances of brynza cheese under the influence of partial replacement of salt with potassium chloride
}

\author{
I. V. Skulska, O. Y. Tsisaryk
}

Stepan Gzhytskyi National University of Veterinary Medicine and Biotechnologies Lviv, Ukraine

Article info

Received 03.02.2020

Received in revised form 05.03 .2020

Accepted 06.03.2020

Stepan Gzhytskyi National University of Veterinary Medicine and Biotechnologies Lviv, ekarska Str., 50, Lviv, 79010, Ukraine.

Tel.: +38-097-854-61-38 Email:inna_skulska@ukr.net
Skulska, I. V., \& Tsisaryk, O. Y. (2020). Changes in protein substances of brynza cheese under the influence of partial replacement of salt with potassium chloride. Scientific Messenger of Lviv National University of Veterinary Medicine and Biotechnologies. Series: Food Technologies, 22(93), 50-54. doi: 10.32718/nvlvet-f9309

The results of studies of protein substances of brine cheese from sheep milk with partial replacement of salt with potassium chloride in the amount of 20 and $30 \%$ are presented in the article. Benefits of cheese as a foodstuff are a large number of vitamins $B, A, E$, it is rich in minerals, including trace elements and essential amino acids. The bacterial preparation RSF-742 in combination with Fresh-Q (Chr. Hansen, Denmark) was used to make the cheese, which adversely affects the development of yeast and mold, thus extending the shelf life of the cheese. Two groups of cheese were made. The first group (without Fresh-Q): $\mathrm{K}$ (control) using $\mathrm{NaCl} ; \mathrm{Dl}$ and $\mathrm{D} 2$ with $20 \%$ and $30 \%$ replacement of $\mathrm{NaCl}$ by $\mathrm{KCl}$, respectively. Second group (with Fresh-Q): $\mathrm{CF}$ using $\mathrm{NaCl}$; DF1 and DF2 with 20 and $30 \%$ replacement of $\mathrm{NaCl}$ by $\mathrm{KCl}$, respectively. The Kjeldahl method was used to determine the content of total Nitrogen, total soluble Nitrogen, Nitrogen of non-protein soluble nitrogen-containing compounds. The positive effect of salt replacement and the use of biosecurity culture on the course of proteolytic processes has been proved. Nitrogen content of soluble protein substances, which determines the dietary properties of cheese, increased in samples with 20 and $30 \%$ replacement of table salt with potassium chloride. Determination of digestibility of proteins by digestive enzymes in vitro was performed using the basic method Pokrovsky-Ertanov. The essence of the method consists in the sequential effect on the protein of the object under study of the proteinase system and the removal by dialysis of some hydrolysis products to avoid inhibition of the reaction by low molecular weight peptides and free amino acids. Brynza with partial replacement of sodium chloride with potassium chloride is characterized by better digestibility compared to cheese, which is made by traditional technology. The data are confirmed by high rates of digestibility. The test specimens of the breeze according to these indicators fully meet the requirements of the current regulatory documentation.

Key words: brynza, brine cheese, potassium chloride, proteolysis, digestibility.

\section{Зміни білкових речовин бринзи під впливом часткової заміни кухонної солі хлоридом калію}

\author{
І. В. Скульська, О. Й. Цісарик
}

Львівський національний університет ветеринарної медицини та біотехнологій імені С. 3. Гљицького, м. Львів, Україна

У статті наведено результати досліджень білкових речовин розсольного сиру бринза з овечого молока за часткової заміни кухонної солі хлоридом калію у кількості 20 і 30 \%. Користь бринзи, як продукту харчування, полягає у великій кількості вітамінів групи B, A, Е, багата вона мінеральними речовинами, у тому числі, мікроелементами і незамінними амінокислотами. Для виготовлення бринзи використано бактеріальний препарат RSF-742 у поєднанні з біозахисною культурою Fresh-Q (Chr. Напsеn, Данія), яка згубно впливає на розвиток дріжджів і плісені, таким чином подовжуючи термін зберігання сиру. Виготовлено 2 групи сирів. Перша група (без Fresh-Q): K (контроль) з використанням NaCl; Д1 і Д2 з 20\% i 30\% заміною $\mathrm{NaCl} \mathrm{на} \mathrm{KCl} \mathrm{відповідно.} \mathrm{Друга} \mathrm{група}$ (з Fresh-Q): KF з використанням NaCl; ДF1 i ДF2 з 20 i $30 \%$ заміною $\mathrm{NaCl} \mathrm{на} \mathrm{КCl} \mathrm{відповідно.} \mathrm{Для} \mathrm{визначення} \mathrm{змісту} \mathrm{загального}$ 
Нітрогену, загального розчинного Нітрогену, Нітрогену небілкових розчинних нітрогеновмісних сполук використовували метод K' єльдаля. Доведено позитивний вплив заміни кухонної солі і використання біозахисної культури на перебіг протеолітичних процесів. Встановлено, шо вміст Нітрогену розчинних білкових речовин, який визначає дієтичні властивості сиру, зростає у зразках з 20 i $30 \%$ заміною кухонної солі хлоридом калію. Визначення перетравлюваності білків травними ферментами іп vіtro проводили з використанням базової методики А. А. Покровського-І. Д. Ертанова. Суть методу полягає у послідовному впливі на білок досліджуваного об'єкта системи протеїназ і видаленні за допомогою діалізу деяких продуктів гідролізу, иоб уникнути пригнічення реакції низькомолекулярними пептидами і вільними амінокислотами. Бринза з частковою заміною хлориду натрію хлоридом калію характеризується кращою засвоюваністю у порівнянні з сиром, який виготовлений за традиційною технологією. Дані підтверджуються високими показниками перетравлюваності. Дослідні зразки бринзи за даними показниками повністю відповідають вимогам діючої нормативної документації.

Ключові слова: бринза, розсольний сир, хлорид калію, протеоліз, перетравлюваність.

\section{Вступ}

Розсольний сир бринза - це молочний продукт масового споживання, який традиційно виготовляють в Карпатському регіоні України 3 овечого молока 3 подальшим його дозріванням в розсолі, концентрація кухонної солі в якому становить 18-20\%. Для цього виду сиру характерна висока біологічна і харчова цінність. Користь бринзи, як продукту харчування, полягає у великій кількості вітамінів групи В, А, Е, багата вона мінеральними речовинами, у тому числі, мікроелементами i незамінними амінокислотами. Неможливо недооцінити користь бринзи для кісток, зубної емалі людини. Кальцій, що входить у бринзу, краще засвоюється організмом людини порівняно 3 іншими молочними продуктами. Включення бринзи в щоденний раціон харчування допомагає значно поліпшити процес травлення організму, прискорити обмін речовин, пригнічувати розвиток гнильних бактерій в кишечнику. Інгредієнти, що входять у бринзу - молочний цукор, білки, жири, мінеральні речовини, 3 легкістю здатні відновити харчовий баланс людини (Kozak et al., 2010).

Характерною особливістю технологічного процесу виготовлення сиру бринза є визрівання у розсолі (Ауyash et al., 2012), при цьому вміст солі в готовому продукті досягає 4-7 \% згідно ДСТУ 7065:2009 (DSTU 7065:2009). Важливим сучасним трендом харчової промисловості є тенденція до зменшення вмісту солі в продуктах харчування, в тому числі і молочних (Kozak et al., 2010; Innocente et al., 2013), яка обумовлена тим, що надмірне споживання солі призводить до появи багатьох захворювань, таких як остеопороз, катаракта, глаукома і серцево-судинні захворювання . Протягом останнього десятиліття в країнах світу вміст натрію в сирах зменшилася на $16 \%$ (Kozak et al., 2010).

Однак зниження вмісту хлориду натрію у продукті впливає на органолептичні показники сиру, що не завжди однозначно сприймається споживачами, а також впливає на показники безпеки продукту (Kozak et al., 2010).

Через зниження вмісту хлориду натрію зростає протеоліз, кислотність, знижується твердість сиру і порушуються ферментативні процеси (Маo et al., 2012). Наприклад, у чеддері це призвело до зниження вмісту водорозчинного азоту, в той час, як заміна $\mathrm{NaCl}$ на $\mathrm{KCl}$ сприяла підвищенню показника активності води (AW), що має важливе значення для формування смаку і консистенції сиру (Мао et al., 2012). Про підвищення вологості сирного зерна, виникнення дефектів текстури сиру, погіршення його смакових якостей і уповільнення ферментативної діяльності повідомляється при зниженні вмісту $\mathrm{NaCl}$ (Mao et al., 2012). Показано також, що зменшення концентрації солі в розсолі від $18 \%$ до $10 \%$ призвело до зниження pH сирного пласта, що пов'язано зі збільшенням вмісту молочної кислоти. Варто звернути увагу на зниження пружності при розжовування і твердість сиру при цьому. Це доводить, що зменшення вмісту солі негативно впливає на його консистенцію (Pokrovs'kyy, 1974).

Існують відомості, що зниження вмісту солі у сирі моцарелла і чеддер сприяє формуванню масляного аромату, при цьому зростає пружність і зменшується жорсткість сирного пласта. Поява гіркоти, на думку дослідників, залежить від вибору культури заквасок, тому правильно іiі обравши, можна уникнути погіршення органолептичних показників (Pokrovskij \& Ertanov, 1965).

Альтернативою зменшення вмісту солі у продукті $\epsilon$ часткова заміна $\mathrm{NaCl}$ на $\mathrm{KCl}$. Хлорид калію $\mathrm{KCl}$, калієва сіль соляної кислоти, є білою кристалічною речовиною і відноситься до структурного типу $\mathrm{NaCl}$ (Aуyash et al., 2012). Вивчення можливості часткової заміни $\mathrm{NaCl}$ при виробництві сирів на $\mathrm{KCl}$ сьогодні $€$ актуальним.

Концентрація солі впливає на біохімічні процеси, що протікають при дозріванні сиру, серед яких зміни білкових речовин вважаються основними. Під впливом сичужного ферменту і ферментів молочнокислих бактерій білки сирної маси розпадаються 3 утворенням численних нітрогеновмісних сполук. Параказеїнаткальційфосфатний комплекс (ПККФК) поступово розпадається на розчинні у воді білкові речовини (високомолекулярні поліпептиди), потім на середньоi низькомолекулярні поліпептиди (пептиди) i, нарешті, на амінокислоти. Одночасно йде відщеплення амінокислот і низькомолекулярних пептидів від поліпептидів. Ферментативний розпад ПККФК супроводжується утворенням розчинних у воді нітрогеновмісних сполук, кількість яких невпинно збільшується. Однак близько 50-80 \% ПККФК (в залежності від виду сиру) залишаються незадіяними у ферментативних процесах. Ступінь розпаду білків при дозріванні сирів визначають, досліджуючи в них нітрогеновмісні сполуки (Grummer et al., 2013). Він залежить від вмісту солі, оскільки вміст солі впливає на мікрофлору, від ферментативної активності якої безпосередньо зале- 
жить ступінь і спрямованість гідролітичних процесів, у тому числі й протеолітичних.

Мета нашої роботи полягає у вивченні впливу часткової заміни кухонної солі хлоридом калію на зміни білкових речовин у бринзі.

\section{Матеріал і методи досліджень}

Для виготовлення бринзи 3 частковою заміною хлориду натрію хлоридом калію (у кількості 20 і $30 \%$ в використовували сичужний фермент СНYMAX (Chr. Hansen, Данія), бактеріальні культури для розсольних сирів RSF-742 і біозахисну культуру Fresh-Q (Chr. Hansen, Данія). Fresh-Q (Lactobacillus rhamnosus) проявляє інгібуючу дію на дріжджі і плісень. Оскільки ми замінили частину хлориду натрію, важливим фрагментом досліджень був пошук шляхів продовження терміну зберігання бринзи, для чого використовували біозахисну культуру Fresh-Q.

Виготовлено 2 групи сирів: $з$ використанням FreshQ і без неї.

Перша група: К (контроль) 3 використанням $\mathrm{NaCl}$; Д1 і Д2 з $20 \%$ і 30 \% заміною $\mathrm{NaCl}$ на $\mathrm{KCl}$ відповідно.

Друга група (з Fresh-Q): KF з використанням NaCl; ДF1 і ДF2 з 20 і 30 \% заміною $\mathrm{NaCl}$ на $\mathrm{KCl}$ відповідно.

Утворення згустку здійснювали при температурі молока $+34 \pm 1^{\circ} \mathrm{C}$. Зазначений температурний режим вважаємо компромісним між температурним оптимумом для термофільних Streptococcus thermophilus i Lactobacillus helveticus і мезофільних Lactococcus lactis subsp. cremoris i Lactococcus lactis subsp. lactis культур, що входять до складу RSF-742.

Для визначення змісту загального Нітрогену, загального розчинного Нітрогену, Нітрогену небілкових розчинних нітрогеновмісних сполук використовували метод К'єльдаля. Вміст Нітрогену розчинних білкових речовин визначали за різницею показників загального розчинного Нітрогену та Нітрогену небілкових розчинних нітрогеновмісних сполук сиру.

Відомо, що біологічна цінність продукту визначається не тільки вмістом у ньому білка, але і його якістю. Найважливіший показник якості білка є його перетравлюваність, тобто здатність гідролізуватися ферментами шлунково-кишкового тракту. Цю властивість вивчають методами in vitro i in vivo. Методи визначення перетравлюваності білків in vitro добре узгоджуються з даними, отриманими in vivo.

Визначення перетравлюваності білків травними ферментами in vitro проводили з використанням базової методики А. А. Покровського - І. Д. Ертанова (Pokrovskij \& Ertanov, 1965; Lipatov et al., 1994). Цей метод - ферментативний, суть його полягає у послідовному впливі на білки досліджуваного об'єкта системою протеїназ і видаленні за допомогою діалізу деяких продуктів гідролізу, щоб уникнути пригнічення реакції низькомолекулярними пептидами і вільними амінокислотами.

Гідроліз здійснювали у спеціальному апараті, який складається з приладу, призначеного для перемішування і нагрівання рідини, оснащеного стрижнем i перемішуючою лопаткою; зовнішньої посудини; внутрішньої посудини, в якості дна в якому використову- ється діалізна плівка, яка прикріплена до нього за допомогою гумки. Внутрішню посудину закривають гумовим корком 3 термометром. Зовнішня посудина це скляна термостійка склянка ємністю 50 мл, внутрішня - порожниста скляна трубка діаметром 3540 мм і довжиною 150-160 мм. Розміри посудин обрані таким чином, щоб дотримувалася умова рівності рівнів рідини у внутрішній і зовнішній посудинах. Магнітна мішалка ММ 2А дозволяє здійснювати постійне перемішування рідини за допомогою скляної мішалки, що знаходиться у внутрішній посудині. Швидкість мішалки підтримують на рівні 60 об/хв, тому що така швидкість близька до частоти перистальтичних скорочень шлунково-кишкового тракту. Також цей прилад дозволяє здійснювати підігрів рідини до температури $+37 \pm 0,5^{\circ} \mathrm{C}$ і її підтримання на цьому рівні. Щоб уникнути випаровування рідини 3 внутрішньої посудини, його щільно закривають гумовим корком 3 термометром для спостереження за температурою процесу гідролізу.

Умови протеолізу, підбір фермент-субстратного співвідношення, оптимальна тривалість проведення реакції і кислотність середовища відповідають умовам в шлунково-кишковому тракті людини.

Перетравлюваність білків оцінювали за наростанням продуктів гідролізу в результаті ферментативного гідролізу.

\section{Результати та їх обговорення}

Біологічна цінність білків визначається їх доступністю, що безпосередньо залежить від ступеня протеолізу при дозріванні сиру. Крім того, низькомолекулярні пептиди і вільні амінокислоти дуже впливають на органолептичні властивості сиру, в першу чергу, на його смак.

Дослідні зразки бринзи за органолептичними показниками повністю відповідали вимогам Стандарту. Однак у порівнянні з контролем вони характеризувались менш щільною консистенцією, більш вираженим сирним смаком і ароматом.

Нами досліджені зміни змісту різних форм Нітрогену в бринзі під час дозрівання в розсолі. Так, на 12 добу (табл. 1) визрівання спостерігали тенденцію до збільшення вмісту загального і загального розчинного Нітрогену в зразках з 20 і 30 \% заміною $\mathrm{NaCl}$ на $\mathrm{KCl}$ у порівнянні 3 відповідним контролем. Застосування препарату Fresh-Q впливало на вміст як загального Нітрогену, так і розчинного у цей період: їх концентрації зросли у порівнянні з бринзою, що виготовилась без Fresh-Q. При цьому зберігалась тенденція, характерна для зразків першої групи.

У зрілій бринзі (табл. 2) високий вміст загального розчинного Нітрогену зареєстровано для зразків 3 20 \% заміною кухонної солі (30,02 і 32,72 мг/г для Д1 і ДF1 відповідно), найнижчим показником характеризувався контрольний зразок К (28,50 мг/г) . За вмістом Нітрогену розчинних білкових з'єднань, що визначає дієтичні властивості сиру, високі показники зареєстровані для бринзи з $20 \%$ заміною $\mathrm{NaCl}$ на $\mathrm{KCl}$ для обох груп сиру (21,32 і 23,62 мг/г Д1 і ДF1 проти 21,2 і 22,72 мг/г для К і КF відповідно). 
Таблиця 1

Нітрогеновмісні сполуки бринзи на 12 добу визрівання $(\mathrm{n}=3, \mathrm{P}<0,05)$

\begin{tabular}{ccccc}
\hline $\begin{array}{c}\text { Зразки } \\
\text { бринзи }\end{array}$ & $\begin{array}{c}\text { Загальний } \\
\text { Нітроген, мг/г }\end{array}$ & $\begin{array}{c}\text { Загальний } \\
\text { розчинний } \\
\text { Нітроген, мг/г }\end{array}$ & $\begin{array}{c}\text { Нітроген небілкових } \\
\text { розчинних нітрогеновмісних } \\
\text { сполук, мг/г }\end{array}$ & $\begin{array}{c}\text { Нітроген розчинних } \\
\text { білкових речовин, мг/г }\end{array}$ \\
\hline К & $28,80 \pm 0,12$ & $14,96 \pm 0,12$ & $2,32 \pm 0,12$ & $12,64 \pm 0,11$ \\
Д1 & $30,50 \pm 0,14$ & $18,54 \pm 0,13$ & $2,50 \pm 0,15$ & $16,04 \pm 0,12$ \\
Д2 & $29,66 \pm 0,13$ & $17,84 \pm 0,16$ & $2,43 \pm 0,13$ & $15,41 \pm 0,12$ \\
КF & $30,80 \pm 0,11$ & $20,02 \pm 0,11$ & $2,38 \pm 0,14$ & $17,64 \pm 0,13$ \\
ДF1 & $31,38 \pm 0,15$ & $26,50 \pm 0,15$ & $2,69 \pm 0,13$ & $23,81 \pm 0,13$ \\
ДF2 & $30,94 \pm 0,15$ & $26,40 \pm 0,14$ & $2,58 \pm 0,12$ & $23,82 \pm 0,11$ \\
\hline
\end{tabular}

Таблиця 2

Нітрогеновмісні сполуки бринзи на 20 добу визрівання (зрілий сир) (n $=3, \mathrm{P}<0,05)$

\begin{tabular}{ccccc}
\hline $\begin{array}{c}\text { Зразки } \\
\text { бринзи }\end{array}$ & $\begin{array}{c}\text { Загальний } \\
\text { Нітроген, мг/г }\end{array}$ & $\begin{array}{c}\text { Загальний } \\
\text { розчинний } \\
\text { Нітроген, мг/г }\end{array}$ & $\begin{array}{c}\text { Нітроген небілкових } \\
\text { розчинних нітрогеновмісних } \\
\text { сполук, мг/г }\end{array}$ & $\begin{array}{c}\text { Нітроген розчинних } \\
\text { білкових речовин, мг/г }\end{array}$ \\
\hline К & $33,48 \pm 0,12$ & $28,50 \pm 0,13$ & $7,30 \pm 0,12$ & $21,20 \pm 0,12$ \\
Д1 & $36,16 \pm 0,14$ & $30,02 \pm 0,13$ & $8,70 \pm 0,14$ & $21,32 \pm 0,14$ \\
Д2 & $35,54 \pm 0,11$ & $29,28 \pm 0,11$ & $8,10 \pm 0,11$ & $21,18 \pm 0,10$ \\
КF & $36,58 \pm 0,12$ & $31,00 \pm 0,11$ & $8,28 \pm 0,12$ & $22,72 \pm 0,12$ \\
ДF1 & $37,96 \pm 0,15$ & $32,72 \pm 0,12$ & $9,10 \pm 0,15$ & $23,62 \pm 0,15$ \\
ДF2 & $37,66 \pm 0,12$ & $32,14 \pm 0,12$ & $9,06 \pm 0,12$ & $23,08 \pm 0,12$ \\
\hline
\end{tabular}

Таким чином, часткова заміна іонів натрію на іони калію впливає на протеолітичні процеси, що проявляється у підвищенні вмісту розчинного білкового Нітрогену.

Характерним при перетравленні бринзи є двоступеневий тип кривої (рис. 1). На першій стадії перетравлення сиру під впливом пепсину можна відзначити стрімкий підйом кривої. Однак до 4-ї години перетравлення відзначається уповільнення гідролізу його білків. Подальше додавання в систему трипсину викликає нове прискорення процесу перетравлення, в результаті чого крива на початку досліду (початок 5- ої години) знову стрімко піднімається вгору. У зв'язку 3 уповільненням гідролізу продуктів, загальний час перетравлюваності склав 8 годин. Дані по перетравлюваності білків бринзи наведені у таблиці 3.

Крива динаміки перетравлюваності білків зразків Д1 і ДF1 характеризується найвищим показником, що підтверджено даними про загальну перетравлюваність зразків бринзи. За підсумками досліджень перетравлюваності білків бринзи можна зробити висновок, що найкращою перетравлюваністю володіють білки зразка ДF1 (82,48 \%) і Д1 (80,35 \%). Також різниця щодо відповідних контролів становить 30,2 і 26,9 \%.
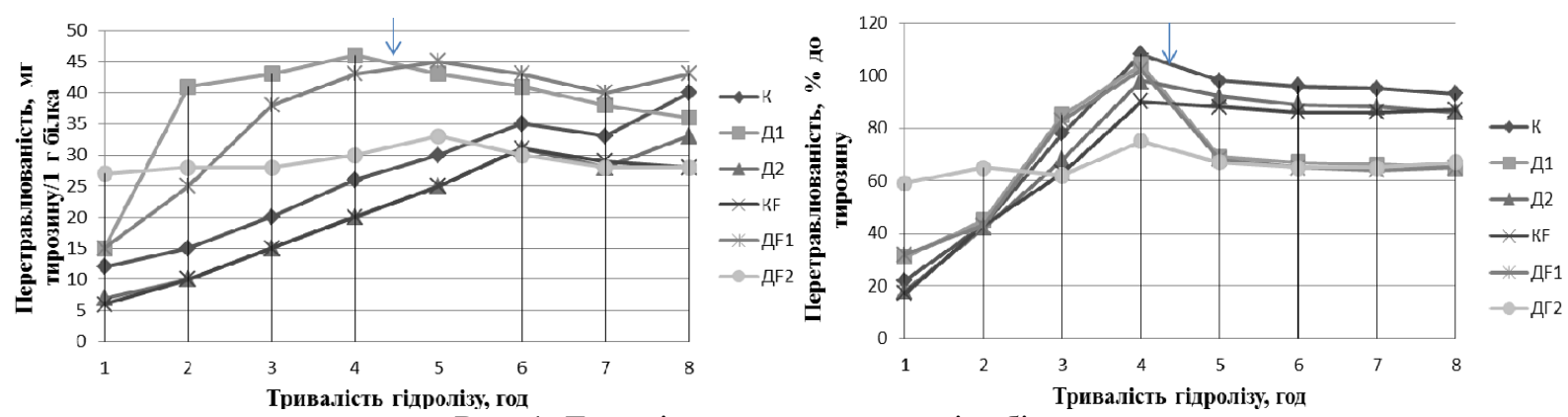

Рис. 1. Динаміка процесу протеолізу білкових систем

(Примітка: стрілка показує момент додавання трипсину у пепсиновий гідролізат)

Таблиця 3

Перетравлюваність бринзи (в умовах in vitro)

\begin{tabular}{|c|c|c|c|c|c|}
\hline \multirow{3}{*}{ Зразок } & \multirow{3}{*}{$\begin{array}{c}\text { Масова частка тирозину, } \\
\text { г/100 г білка }\end{array}$} & \multicolumn{4}{|c|}{ Перетравлюваність білків } \\
\hline & & \multicolumn{3}{|c|}{ мг тирозину/г білка } & \multirow{2}{*}{$\%$} \\
\hline & & пепсином & трипсином & сумарне & \\
\hline $\mathrm{K}$ & $4,45 \pm 0,15$ & $6,75 \pm 0,12$ & $20,71 \pm 0,20$ & $27,46 \pm 0,22$ & 61,71 \\
\hline Д1 & $4,45 \pm 0,19$ & $9,91 \pm 0,12$ & $25,84 \pm 0,25$ & $35,75 \pm 0,30$ & 80,35 \\
\hline Д2 & $4,45 \pm 0,15$ & $8,12 \pm 0,11$ & $22,65 \pm 0,19$ & $30,77 \pm 0,34$ & 69,15 \\
\hline $\mathrm{KF}$ & $4,45 \pm 0,14$ & $8,85 \pm 0,11$ & $20,07 \pm 0,21$ & $28,92 \pm 0,20$ & 64,99 \\
\hline ДF1 & $4,45 \pm 0,22$ & $11,24 \pm 0,15$ & $25,46 \pm 0,26$ & $36,70 \pm 0,38$ & 82,48 \\
\hline ДF2 & $4,45 \pm 0,15$ & $10,34 \pm 0,11$ & $23,33 \pm 0,17$ & $33,67 \pm 0,29$ & 75,65 \\
\hline
\end{tabular}




\section{Висновки}

Виготовлено бринзу з частковою (20 і $30 \%$ ) заміною хлориду натрію хлоридом калію. У бринзі з $20 \%$ заміною кухонної солі хлоридом калію активніше відбуваються протеолітичні процеси. Доведено позитивний вплив часткової заміни кухонної солі на вміст розчинного білкового Нітрогену. Також слід зазначити, що сир, який виготовлений із заміною кухонної солі хлоридом калію у кількості 20 і 30 \%, характеризується кращою перетравлюваністю у порівнянні 3 сиром, який виготовляються за традиційною технологією.

\section{References}

Ayyash, M. M., Sherkat, F., \& Shah, N. P. (2012). The effect of $\mathrm{NaCl}$ substitution with $\mathrm{KCl}$ on Akawi cheese: Chemical composition, proteolysis, angiotensinconverting enzyme-inhibitory activity, probiotic survival, texture profile, and sensory propepties. J. Dairy Sci., 95(9), 4747-4759. doi: 10.3168/jds.2011-4940.

DSTU 7065:2009. Brynza. Zahal'ni tekhnichni umovy (in Ukrainian).

Ganesan, B., Brown, K.M., Irish, D.A., Brothersen, C., \& McMahon, D.J. (2014). Manufacture and sensory analysis of reduced- and low-sodium Cheddar and Mozzarella cheeses. J. Dairy Sci., 97(4), 1970-1982. doi: 10.3168/jds.2013-7443.

Grummer, J., Bobowski, N., Karalus, M., Vickers, Z., \& Schoenfuss, T. (2013). Use of potassium chloride and flavor enhancersin low sodium Cheddar cheese. J. Dairy Sci., 96(3), 1401-1418. doi: 10.3168/jds.20126057.
Innocente, N., Munari, M., \& Biasutti, M. (2013). Characterization by solid-phase microextraction-gas chromatography of the volatile profile of protected designation of origin Montasio cheese during ripening. J. Dairy Sci., 96(1), 26-32. doi: 10.3168/jds.2012-5689.

Kamleh, R., Olabi, A., Toufeili, I., Najm, N. E. O., Younis, T., \& Ajib, R. (2012). The effect of substitution of sodium chloride with potassium chloride on the physicochemical, microbiological, and sensory properties of Halloumi cheese. J. Dairy Sci., 95(3), 11401151. doi: 10.3168/jds.2011-4878.

Kozak, M. V., Hachak, YU. R., \& Nahovs'ka, V. O. (2010). Osoblyvosti vyrobnytstva sychuzhnykh i plavlenykh syriv ta yikh sanitarna otsinka. L'viv (in Ukrainian).

Lipatov, N. N., Judina, S. B., \& Lisicin, A. B. (1994). Usovershenstvovannyj pribor i metodika dlja opredele-nija perevarimosti belkov in vitro. Voprosy pitanija, 4, 43-44 (in Russian).

Mao, M. Y., Tong, P. S., Gualco, S., \& Vinkt, S. (2012). Effect of $\mathrm{NaCl}$ addition during diafiltration on the solubility, hydrophobicity, and disulfide bonds of $80 \%$ milk protein concentrate powder. J. Dairy Sci., 95(7), 3481-3488. doi: 10.3168/jds.2011-4691.

Pokrovskij, A. A., \& Ertanov, I. D. (1965). Atakuemost' belkov pishhevyh produktov proteoliticheskimi fermentami in vitro. Voprosy pitanija, 3, 38-44 (in Russian).

Pokrovs'kyy, A. A. (1974). Rol' biokhimiyi u rozvytku nauky pro kharchuvannya: Deyaki zakonomirnosti asymilyatsiyi kharchovykh rechovyn na rivni klityny $\mathrm{i}$ tsilisnoho orhanizmu. M.: Nauka (in Ukrainian). 